\title{
The Use of Decomposition Methods to Understand the Economic Growth Gap between Latin America and East Asia
}

\author{
Beatriz Barrado $^{1, *(\mathbb{D})}$, Gregorio Gimenez ${ }^{1}$ (D) and Jaime Sanaú ${ }^{1,2}$ \\ 1 Faculty of Economics and Business Administration, University of Zaragoza, 50005 Zaragoza, Spain; \\ gregim@unizar.es (G.G.); jsanau@unizar.es (J.S.) \\ 2 Institute of Employment, Digital Society and Sustainability, University of Zaragoza, 50005 Zaragoza, Spain \\ * Correspondence: beatricevicent@gmail.com
}

check for

updates

Citation: Barrado, B.; Gimenez, G.; Sanaú, J. The Use of Decomposition Methods to Understand the Economic Growth Gap between Latin America and East Asia. Sustainability 2021, 13, 6674. https://doi.org/10.3390/ su13126674

Academic Editors: Pompeo Della

Posta, Enrico Marelli and

Marcello Signorelli

Received: 17 May 2021

Accepted: 7 June 2021

Published: 11 June 2021

Publisher's Note: MDPI stays neutral with regard to jurisdictional claims in published maps and institutional affiliations.

Copyright: (c) 2021 by the authors. Licensee MDPI, Basel, Switzerland. This article is an open access article distributed under the terms and conditions of the Creative Commons Attribution (CC BY) license (https:// creativecommons.org/licenses/by/ $4.0 /)$.

\begin{abstract}
Understanding how growth factors contribute to explaining the large differences in growth rates across countries remains an important research agenda. The common approach to exploring this issue is based on the use of multiple linear regression analyses. This work contributes to growth literature by applying a new perspective based on the use of variance decomposition procedures: Shapley-Owen-Shorrocks and Oaxaca-Blinder. These methodologies have four main advantages with respect to traditional methodologies: they make possible the quantification of the relative contribution of each factor to economic growth, they allow us to estimate the efficiency in the use of the endowments of each factor, they can be used with any functional form and they can be used with estimation methods that are robust regarding endogeneity issues. We illustrate these advantages by analyzing the causes of the economic growth gap between Latin America and East Asia over the period 1980-2014. We find that the economic growth divergence between the two regions can be primarily explained by the differences in institutions and physical capital. In addition, the results indicate that the higher East Asian performance is not only due to its higher levels of endowments in these factors, but also to the higher efficiency in its use. We connect our results with the 2030 Agenda for Sustainable Development.
\end{abstract}

Keywords: Latin America; East Asia; economic growth; sustainable development; investment; human capital; institutions; Oaxaca-Blinder; Shapley-Owen-Shorrocks

\section{Introduction}

The 2030 Agenda for Sustainable Development recognizes explicitly the importance of promoting economic growth (goal 8) to achieve sustainable development. This Agenda, adopted in 2015 as a result of a global political effort, sets 17 Sustainable Development Goals (SDGs) to promote sustainable development. This concept, proposed by the seminal Brundtland Report [1], focuses on the improvement of living conditions while protecting the planet and ensuring prosperity for all and future generations [2-7].

In this context, identifying which growth factors contribute to explaining the large differences in growth rates across countries is key to knowing how to prioritize policies to make effective progress toward the SDGs. Understanding why some countries grow more than others remains one of the most important topics in the economists' research agenda, because of its consequences on well-being. Following the seminal work of Barro [8], an increasing number of empirical studies have tried to estimate the extent to which economic growth factors contribute to explaining the huge differences in income among countries. To date, the most common approach to resolve this question has been based on the use of multiple linear regression analyses and statistical significance $[9,10]$. There are several limitations inherent to the use of this approach. The coefficients of these regressions give information about the sense of the correlation between variables and its significance. However, "a p-value, or statistical significance, does not measure the size of an effect or the importance of a result" [11]. They do not allow researchers to rank the explanatory variables 
in order of importance and, hence, they do not allow for the quantification of the true contribution of each variable to explain economic growth $[12,13]$.

To overcome such limitations, this work contributes to growth and sustainable literature by applying an alternative approach based on variance decomposition procedures. Although these decomposition techniques have been used in different fields in economy, they have hardly been applied to the empirical study of economic growth, in spite of their advantages. These techniques have been used, for example, to understand the causes of inequality and poverty $[14,15]$ and differences in wages $[16,17]$ and in educational achievement [18-23]. Firstly, they make possible the quantification of the relative contribution of explanatory variables and, therefore, the identification of which factors have contributed the most to economic growth. Secondly, they allow us to estimate the efficiency in the use of the endowments of factors. Thirdly, these methodologies can be used with any functional form, regardless of the complexity of the model or the number and types of factors considered. Finally, in growth models endogeneity is a key problem, that usually arises due to reverse causality, omitted variables and measurement errors. Decomposition techniques allow us to tackle endogeneity issues, because they can be applied using estimation methods (as instrumental variables) that are robust with regard to endogeneity [24].

The combination of these decomposition methods, traditionally applied in the poverty and labor economics fields, and our application to analyze the divergence between Latin America and East Asia, represent a novelty in relation to previous studies. The results show that the decomposition procedures allow for a deeper analysis of the causes of the differences in economic growth. The better East Asian performance can be largely explained by their higher levels of endowments in institutional factors and physical capital. Furthermore, the higher East Asian growth compared to that of Latin America is not uniquely explained by its higher endowments. They also use human resources, physical capital and institutional factors more efficiently.

The paper is organized as follows. Section 2 offers a revision of the limitations of the conventional approaches to study economic growth and a summary of the advantages of the variance decomposition methodologies in economic growth studies and of the use of OBD and SOSD to understand East Asia's and Latin America's growth performance. Section 3 presents the empirical strategy based on a Shapley-Owen-Shorrocks decomposition (SOSD) and a Oaxaca-Blinder decomposition (OBD), and describes the baseline model and data. Section 4 presents the results and their discussion. Finally, Section 5 includes the conclusions and policy recommendations as well as the limitations and possible future research directions.

\section{Conceptual Framework}

\subsection{Limitations of Traditional Economic Approaches to Study the Factors of Economic Growth}

Why do some countries grow more than others? Describing the facts that explain economic growth differences across countries is still an unresolved question [10]. We can synthetize two the main approaches used to answer this question in the literature. The first refers to the Solow decomposition. Following Solow's seminal research, empirical work on economic growth has been based on accounting exercises and the role of technological efficiency, namely "total factor productivity" [25]. Despite its extensive use, some limitations have been pointed out in the literature. The total factor productivity can be seen as the result of shifts in the production function, and these are sensitive to underlying assumptions about the nature of the production process. In addition, the shifts could reflect the effect of other factors, different from technological innovation [26,27], among which external shocks, changes in government policies, institutional and cultural issues, or measurement errors. The use of the expression "Solow residual" to refer to this decomposition gives a clear idea of its limitations.

The second approach has attempted to address issues of cross-country economic differences using multiple linear regression analysis. Most studies are based on the models originally developed by Barro [8] and Mankiw et al. [28]. These ad hoc alla Barro 
regressions explain the per capita output growth rates as a function of initial income, savings, population growth and a set of variables that includes physical and human capital, innovation and institutions. For a complete review of these models and their empirical application, see $[9,10,29]$.

Given the vast number of proposed growth determinants in the literature, researchers are faced with a dilemma regarding the potential regressors that lie behind model uncertainty. Thousands of regressions have been estimated following a common strategy to assess the importance of explanatory variables based on the sense of their correlation with growth and their significance. Accordingly, different studies have used the Bayesian Model Averaging approach to address model uncertainty $[9,30]$. However, although this approach allows us to deal with the restrictions of the number of regressors, this method is limited, given that it cannot explain the contribution of each variable to economic growth [31,32].

A major criticism of these regressions is that it is subject to endogeneity problems. Economic growth variables are endogenous, and hence it is a hard task to estimate the causal effect of an explanatory variable on economic growth [33]. A common strategy to mitigate endogeneity is to use instrumental variables. While this estimation technique is the standard solution to deal with the econometric problems caused by endogeneity, the appropriateness of instrumental variable methods is not obvious. Theoretically, this strategy works if instrumental variables are correlated with the endogenous regressor but uncorrelated with the error. However, it is widely known that choosing the appropriate instruments is a critical issue in the empirical growth literature [30,34].

While these approaches are useful to identify which factor drives the economic growth, many of the central issues of interest for growth empiricists remain unclear: no consensus has emerged about the relative contribution of each factor to explain growth. We integrate the decomposition methods discussed below to deal with the limitations appointed. Specifically, the contribution of each factor to explain economic growth, the efficiency in their use and the multicollinearity and the endogeneity issues are common in this kind of econometric models.

\subsection{Variance Decomposition Methodologies and Their Advantages in Economic Growth Studies}

Decomposition techniques are used in many fields of economics to help disentangle and quantify the impact of causal factors. Among these techniques, the most common are SOSD and OBD. Appendix A includes a mathematical explanation of how to calculate them. These decomposition methods are easy to apply and only require coefficient estimates from regressions for the outcome of interest and sample means of the explanatory variables used in the regression. Nevertheless, they have not yet been applied to the growth field. We intend to fill this gap by showing how these procedures are a suitable approach to study sustainable economic growth. Unlike the traditional methods, the decomposition procedures have the advantage of going beyond a determination of the correlation between variables. Indeed, they enable us to estimate the contribution of any explanatory factor included in the model (linear and nonlinear), and hence identify the main drivers of economic growth. Moreover, a value added of these approaches is the ability to distinguish between the differences in endowments and the differences in efficiency in the use of this endowments. Finally, an important advantage of this technique to be applied to the field of economic growth is that it can be used with estimation methods that are robust with regard to endogeneity issues [24].

\subsection{The Use of OBD and SOSD to Understand East Asia's and Latin America's Growth Performance}

The divergence between Latin America and East Asia is one of the most interesting cases in economic growth studies. The economic experiences during the last decades have been clearly different. Compared to East Asia, Latin America's growth performance has been disappointing. For Latin America as a whole, the average per capita GDP growth was $1.41 \%$ from 1980 to 2014 , compared to $4.12 \%$ in East Asia over the same period (see Table A2 of Appendix B). 
Based on cross-country Barro-style growth regressions, an increasing number of empirical studies have attempted to determine why East Asian countries grow faster than Latin American economies. Differences in fundamental growth factors such as physical capital [29,35,36], human resources [37-39] and institutional factors [40-43] have been identified as key. While our study is clearly not the first attempt to address the causes of the economic divergence between the two regions, our econometric approach represents an important novelty: we complement this literature using decomposition procedures.

\section{The Baseline Model and Data}

The decomposition methodologies are applied to an extended version of the augmented neoclassical growth model $[25,28]$. In particular, our baseline specification model follows that of Barro and Sala-i-Martin [9], which includes a representative set of the explanatory variables and represents a standard model in the empirical literature. A reduced form of the model can be represented by:

$$
g_{i t}=\beta_{0}+\beta_{1} \log y_{i t_{0}}+\beta_{2} Z_{i t}+\varepsilon
$$

where $g_{i t}$ is the average growth rate of per capita income in the period, $\log y_{i t_{0}}$ is the $\log$ value of the initial level of per capita income that captures the conditional convergence, $Z_{i t}$ is a vector that represents the external environment and policy variables, including physical capital, human resources and institutional factors. Lastly, $\varepsilon$ is a random error term.

This growth equation is estimated using a five-year panel data set over the period 1980-2014. Our sample covers 21 Latin American and Caribbean and nine East Asian economies. The selection of countries is common in comparative studies on Latin America and East Asia (see [41]). The data are taken from the Quality of Government (Qi) Institute at the University of Gothenburg and supplemented by Penn World Table 9.0. Appendix B provides a complete description of the variables, sources, the list of economies used in the analysis and the correlation matrix for both regions.

The inclusion of physical capital as an explaining factor of growth has been widely studied [29], but its effect is conditioned by the fertility rate that has a negative effect on the accumulation of physical capital per worker [9,44-46].

Regarding human resources, human capital stock and health attainment are taken into consideration. Human capital is measured as the average years of schooling of males above 15 years old $[47,48]$. A substantial number of studies have found a significant positive association between this measure of human capital and economic growth in both developed and developing countries [49-51], through a direct effect in the production function and an indirect one through innovation, imitation and the quality of institutions [50,52-54]. Measures of education quality, based on internationally comparable test scores, have shown an important explanatory power for growth. Unfortunately, variables as results of the international test of competencies are still unavailable for most developing countries, or they only exist for short time periods, and hence we cannot include these data in our analysis. Human capital can also be accumulated by improving the health status of the population [55], and the empirical literature has found a positive effect of health on economic growth [56,57]. The reciprocal of log value life expectancy at age one is used to measure health attainment, as suggested by Barro and Sala-i-Martin [9].

Among the institutional and policy variables, government consumption, democracy, rule of law, openness, trade and inflation rate are included. Government consumption is widely seen as having an important role on economic growth [8,58-60]. It is measured by its ratio with respect to GDP. Institutional quality is measured by the rule of law index [61]. Although a wide set of institutional variables have been used in empirical literature, the rule of law is considered to have one of the highest explanatory powers for economic growth [62-65]. We also include democracy, as it is considered the most important measure for the quality of political institutions [66], although the findings obtained in the relationship between democracy and growth are often ambiguous [67]. International openness and trade have also been commonly considered in economic growth models. 
Economies open to trade have greater access to cheap imported intermediate goods, large markets and advanced technologies and tend to growth faster [68-71]. The economy's openness is measured by the ratio of exports plus imports to GDP, and trade is measured as the growth ratio of export to import prices. Finally, the model includes the average inflation rate as a proxy of macroeconomic stability. Establishing and maintaining low inflation can reduce uncertainty in the economy and enhance investment decisions [72,73].

The proposed model and approach as well as the data used allow us not only to explain the growth of both areas but also to analyze the interrelationships between some SDGs, such as goal 4 "Quality education", goal 8 "Decent work and economic growth", goal 9 "Industry, innovation and infrastructure" and goal 16 "Peace, justice and strong institutions".

\section{Empirical Results}

Our analytical framework consists of three stages. First, we begin with a regression framework, and we estimate the baseline model for Latin America and East Asia. Second, we apply the SOSD to estimate how much each of the traditional growth factors contributes to explaining growth in Latin America and East Asia. In a third step, we apply the OBD to decompose the growth gap between both regions in terms of differences in factor endowments and the efficiency in their use.

\subsection{Results of Growth Regressions}

Table 1 presents growth regressions. Estimations were obtained using Ordinary Least Squares (OLS) with random effects. The appropriateness of OLS estimation relative to instrumental variable methods was checked using a Durbin-Wu-Hausman specification test.

Table 1. Baseline estimates of growth regression.

\begin{tabular}{|c|c|c|}
\hline & Latin America & East Asia \\
\hline & (1) & (2) \\
\hline \multirow[t]{2}{*}{ Initial income in each period } & -0.081 & -0.174 \\
\hline & $(0.129)$ & $(0.157)$ \\
\hline \multirow[t]{2}{*}{ Investment ratio } & $0.082 * *$ & $0.193^{* * *}$ \\
\hline & $(0.039)$ & $(0.054)$ \\
\hline \multirow[t]{2}{*}{ Log fertility rate } & $-2.380 *$ & $-3.780^{* * *}$ \\
\hline & $(1.265)$ & $(1.230)$ \\
\hline \multirow{2}{*}{ Average schooling years } & 0.160 & $0.588^{* * *}$ \\
\hline & $(0.192)$ & $(0.151)$ \\
\hline \multirow[t]{2}{*}{ Reciprocal of life expectancy } & -172.870 & $1942.34^{* *}$ \\
\hline & $(370.223)$ & $(903.402)$ \\
\hline \multirow[t]{2}{*}{ Government consumption ratio } & $-7.555^{*}$ & 21.062 \\
\hline & $(4.125)$ & $(13.777)$ \\
\hline \multirow[t]{2}{*}{ Democracy Index } & 0.755 & 0.130 \\
\hline & $(0.680)$ & $(0.913)$ \\
\hline \multirow[t]{2}{*}{ Rule of law } & 0.069 & $-2.831^{* * *}$ \\
\hline & $(0.250)$ & $(0.448)$ \\
\hline \multirow[t]{2}{*}{ Openness ratio } & -0.789 & 0.564 \\
\hline & $(1.498)$ & $(0.379)$ \\
\hline \multirow{2}{*}{ Trade } & -0.007 & 0.011 \\
\hline & $(0.027)$ & $(0.014)$ \\
\hline \multirow[t]{2}{*}{ Inflation rate } & -0.006 & $-0.247^{* *}$ \\
\hline & $(0.004)$ & $(0.104)$ \\
\hline \multirow[t]{2}{*}{ Constant } & 5.730 & $-30.179 * *$ \\
\hline & $(4.769)$ & $(12.268)$ \\
\hline$n$ & 137 & 52 \\
\hline R square overall & 0.346 & 0.741 \\
\hline
\end{tabular}

Notes: Dependent variable: annual GDP per capita growth. We test for endogeneity by performing the Durbin-WuHausman specification test using the available 5-year lagged variables as instruments. Test results ( $p$-values are 0.57 and 0.80 for East Asia and Latin America, respectively) do not reject the null hypothesis, suggesting that variables are exogenous and the Ordinary Least Square is preferred to instrumental variables estimation. Panel estimations using random effects. Standard deviations are reported in parentheses. ${ }^{* * *} p<0.01,{ }^{* *} p<0.05,{ }^{*} p<0.1$. 
Column (1) presents the results for the Latin American region. Results show that the investment ratio is positively and significatively correlated with economic growth. The fertility rate and government consumption are negative and significative.

Column (2) shows the regression for the East Asia region. Results shows that the investment ratio, average schooling years and reciprocal of life expectancy have a positive and significant relationship with economic growth. The rule of law and inflation rate are negatively correlated with economic growth. The rest of the variables are not significant.

\subsection{Sources of Growth in Latin America and East Asia: Results from the SOSD}

Table 2 presents the SOSD of the economic growth variability in each region. While multiple linear regressions do not allow us to deduce how factors have contributed to the economic performance of each region, SOSD decomposes the R-square in shares associated with each variable. The results are both in levels and as a percentage of the total variance. Each component is accompanied by its $95 \%$ level confidence interval, that was computed using a nonparametric bootstrap estimation with 1000 replications. So, we calculate a distribution for each component, from which we have computed the 2.5 and the 97.5 percentiles. It is not possible to estimate the significance of the components, as the R-square always rises when an additional explanatory variable is introduced into the regression [12]).

Table 2. Shapley-Owen-Shorrocks decomposition of the variance of economic growth over the period 1980-2014.

\begin{tabular}{|c|c|c|c|c|}
\hline \multirow{2}{*}{ Contributing Factors } & \multicolumn{2}{|c|}{ Latin America } & \multicolumn{2}{|c|}{ East Asia } \\
\hline & Value & Percentage of R-Square & Value & Percentage of R-Square \\
\hline Initial income & $\begin{array}{c}0.005 \\
(0.001,0.026)\end{array}$ & $1 \%$ & $\begin{array}{c}0.022 \\
(0.006,0.078)\end{array}$ & $3 \%$ \\
\hline \multicolumn{2}{|c|}{ Physical capital } & $34 \%$ & & $49 \%$ \\
\hline Investment rate & $\begin{array}{c}0.03 \\
(0.004,0.092)\end{array}$ & $8 \%$ & $\begin{array}{c}0.266 \\
(0.165,0.392)\end{array}$ & $35 \%$ \\
\hline Log fertility rate & $\begin{array}{c}0.093 \\
(0.046,0.155)\end{array}$ & $26 \%$ & $\begin{array}{c}0.105 \\
(0.031,0.205)\end{array}$ & $14 \%$ \\
\hline \multicolumn{2}{|c|}{ Human capital } & $35 \%$ & & $11 \%$ \\
\hline Average schooling years & $\begin{array}{c}0.059 \\
(0.021,0.116)\end{array}$ & $16 \%$ & $\begin{array}{c}0.032 \\
(0.016,0.061)\end{array}$ & $4 \%$ \\
\hline Reciprocal of life expectancy & $\begin{array}{c}0.065 \\
(0.026,0.132)\end{array}$ & $18 \%$ & $\begin{array}{c}0.048 \\
(0.023,0.099) \\
\end{array}$ & $6 \%$ \\
\hline \multicolumn{2}{|c|}{ Institutional and policy variables } & $30 \%$ & & $37 \%$ \\
\hline Government consumption & $\begin{array}{c}0.035 \\
(0.004,0.096)\end{array}$ & $10 \%$ & $\begin{array}{c}0.018 \\
(0.007,0.07)\end{array}$ & $2 \%$ \\
\hline Democracy & $\begin{array}{c}0.021 \\
(0.003,0.082)\end{array}$ & $6 \%$ & $\begin{array}{c}0.048 \\
(0.011,0.133)\end{array}$ & $6 \%$ \\
\hline Rule of law & $\begin{array}{c}0.003 \\
(0.001,0.019)\end{array}$ & $1 \%$ & $\begin{array}{c}0.13 \\
(0.057,0.224)\end{array}$ & $17 \%$ \\
\hline Openness rate & $\begin{array}{c}0.007 \\
(0.001,0.05)\end{array}$ & $2 \%$ & $\begin{array}{c}0.016 \\
(0.008,0.037)\end{array}$ & $2 \%$ \\
\hline Trade & $\begin{array}{c}0.009 \\
(0.001,0.072)\end{array}$ & $3 \%$ & $\begin{array}{c}0.009 \\
(0.003,0.029)\end{array}$ & $1 \%$ \\
\hline Inflation & $\begin{array}{c}0.031 \\
(0.005,0.099)\end{array}$ & $9 \%$ & $\begin{array}{c}0.06 \\
(0.011,0.162)\end{array}$ & $8 \%$ \\
\hline Total R square & 0.358 & $100 \%$ & 0.754 & $100 \%$ \\
\hline Observations & 137 & & 52 & \\
\hline
\end{tabular}

Notes: Dependent variable: annual GDP per capita growth. We test for endogeneity by performing the Durbin-Wu-Hausman specification test using the available 5-year lagged variables as instruments. Hausman test results ( $p$-values are 0.57 and 0.80 for East Asia and Latin America, respectively) do not reject the null hypothesis, suggesting that variables are exogenous and the Ordinary Least Square is preferred to instrumental variables estimation. Panel estimations using random effects. Ninety-five per cent confidence intervals are reported in parentheses. They have been obtained using a nonparametric bootstrap estimation with 1000 replications. Decompositions performed with the rego Stata command developed by Huettner and Sunder [74]. 
Columns (1) and (2) present the results for the Latin American region. According with SOSD, Latin American growth variability can be mainly explained by human resources. They account for about 35\% of the total variance. Physical capital, which has a contribution of $34 \%$, is the second largest contributor, and, finally, institutional factors explain $30 \%$ of the R-square. Columns (3) and (4) show the results for East Asia. Physical capital and institutional factors are the most important explanatory factors. They account for $49 \%$ and $37 \%$ of the R-square, respectively. Specifically, investment (35\%) and rule of law (17\%) are the factors that most contribute to explain the East Asian growth variability. The contributions of human resources and the initial income level are moderate.

These results can be interpreted in terms of the SGDs. The economic growth of Latin America in the period (goal 8) has been possible, to a large extent, due to the improvement of educational quality and human capital (goal 4), the increase in physical capital (goal 9) and the institutional factors (goal 16). In the case of East Asian countries, goal 9 (physical capital) and 16 (institutions) have contributed to goal 8 (economic growth) more than to goal 4 (educational quality).

\subsection{Decomposing the Growth Gap between Latin America and East Asia: Results from the OBD}

Multiple linear regression analysis and SOSD have not explained which factors contribute the most to the growth divergence between the two regions. To further understand the potential factors that drive the gap between Latin America and East Asia, the OBD was employed. Table 3 shows that, for the Latin America region, the predicted growth rate of the model is $1.49 \%$, while in East Asia it is 3.95\%. The difference in the estimated value of the GDP rates is $2.46 \%$, and according to the OBD this gap is statistically significant.

Columns 2-4 show the detailed decomposition of the endowment effects, coefficients effect and interaction effects for each variable. A positive sign is interpreted as increasing the growth difference in favor of East Asia, while a negative sign reduces the gap and favors Latin America. The gap between Latin America and East Asia is due to differences in endowments (the total endowments effect is 8.50), in coefficients (the total effect is 1.16) and in the interaction effect (which measures the simultaneous effect of differences in endowments and coefficients and is -7.21). Therefore, East Asian growth is higher than the Latin American one, due to its higher factor endowments and their use. From these effects we can infer that the part of the difference explained by the model and which is due to differences in endowments accounts for $50.38 \%$ versus $49.62 \%$ for the unobserved component.

The results by each group of variables-initial income, physical and human resources and institutional and macroeconomic variables-are also summarized. According to the endowment effects, the observed economic growth difference between Latin America and East Asia can be mainly explained by institutional factors and physical capital. The positive coefficients indicate that the endowments in these factors have favored, on average, the growth of East Asian economies relative to Latin American countries, and hence they have contributed to increase the gap. Within this group of variables, inflation (6.22) and investment rate (1.92) are the significant elements that most help to explain the gap between the two regions. Regarding human resources, the average of schooling years is positive and only significant at a 10\% confidence level. This indicates that this factor has favored the higher East Asian performance. However, its contribution to explain the gap between the two regions has been lower.

As to the efficiency in the use of the factors, the coefficient effects in Column 3 show that the higher East Asia's growth is not only due to the fact that East Asia has higher levels of endowments. They do a better use of most factors. Specifically, the coefficient effects are significant in the case of human resources, investment and government consumption. On the contrary, the negative sign of the rule of law and the inflation indicates that East Asian governments have been less effective than Latin American ones in taking advantage of these institutional and stability factors. 
Results show that the drivers of economic growth over the period 1980-2014 have been different in East Asia and Latin America. The application of the decomposition methods provide a deeper understanding of the causes of growth in both regions and reveals a number of new insights.

Table 3. Oaxaca-Blinder Decomposition Results of The Economic Growth Gap Between Latin America And East Asia Over The Period 1980-2014.

\begin{tabular}{|c|c|c|c|c|}
\hline & Differential & Endowments & Coefficients & Interaction \\
\hline & (1) & (2) & (3) & (4) \\
\hline Prediction East Asia & $\begin{array}{c}3.950 * * * \\
(0.396)\end{array}$ & & & \\
\hline Prediction Latin America & $\begin{array}{l}1.493^{* * *} \\
(0.220)\end{array}$ & & & \\
\hline Difference & $\begin{array}{c}2.456 * * * \\
(0.453)\end{array}$ & & & \\
\hline Total effect & & $\begin{array}{l}8.502 * * * \\
(2.642)\end{array}$ & $\begin{array}{c}1.164 \\
(1.212)\end{array}$ & $\begin{array}{l}-7.210 * * \\
(2.830)\end{array}$ \\
\hline \multicolumn{5}{|l|}{ Decomposition by factors } \\
\hline Initial income & & $\begin{array}{l}-0.348 \\
(0.455)\end{array}$ & $\begin{array}{l}-1.225 \\
(3.574)\end{array}$ & $\begin{array}{c}0.186 \\
(0.543)\end{array}$ \\
\hline Physical capital & & $\begin{array}{c}3.265^{* * * *} \\
(0.584)\end{array}$ & $\begin{array}{l}2.298 \\
(2.262)\end{array}$ & $\begin{array}{c}-1.598^{*} \\
(0.884)\end{array}$ \\
\hline Investment rate & & $\begin{array}{l}1.916^{* * *} \\
(0.455)\end{array}$ & $\begin{array}{l}3.345^{*} \\
(1.953)\end{array}$ & $\begin{array}{l}-1.098^{*} \\
(0.651)\end{array}$ \\
\hline Log of Fertility rate & & $\begin{array}{c}1.349^{* * * *} \\
(0.437)\end{array}$ & $\begin{array}{l}-1.046 \\
(1.200)\end{array}$ & $\begin{array}{l}-0.500 \\
(0.578)\end{array}$ \\
\hline Human capital & & $\begin{array}{c}0.406 \\
(0.290)\end{array}$ & $\begin{array}{l}32.406^{* *} \\
(14.190)\end{array}$ & $\begin{array}{l}-0.218 \\
(0.345)\end{array}$ \\
\hline Average schooling years & & $\begin{array}{l}0.620 * \\
(0.322)\end{array}$ & $\begin{array}{l}3.285 \\
(2.072)\end{array}$ & $\begin{array}{l}-0.451 \\
(0.326)\end{array}$ \\
\hline $\begin{array}{l}\text { Reciprocal of Life } \\
\text { expectancy }\end{array}$ & & $\begin{array}{l}-0.214 \\
(0.298)\end{array}$ & $\begin{array}{l}29.120 * * \\
(13.350)\end{array}$ & $\begin{array}{c}0.233 \\
(0.326)\end{array}$ \\
\hline $\begin{array}{l}\text { Institutional and policy } \\
\text { variables }\end{array}$ & & $\begin{array}{l}5.180^{* *} \\
(2.495)\end{array}$ & $\begin{array}{c}3.594 \\
(2.473)\end{array}$ & $\begin{array}{c}-5.580 * * \\
(2.557)\end{array}$ \\
\hline Government consumption & & $\begin{array}{c}0.091 \\
(0.157)\end{array}$ & $\begin{array}{l}4.581 * * \\
(1.808)\end{array}$ & $\begin{array}{l}-0.124 \\
(0.210)\end{array}$ \\
\hline Democracy & & $\begin{array}{l}-0.047 \\
(0.255)\end{array}$ & $\begin{array}{l}-0.298 \\
(0.451)\end{array}$ & $\begin{array}{l}-0.228 \\
(0.346)\end{array}$ \\
\hline Rule of law & & $\begin{array}{c}-1.279 * * * \\
(0.433)\end{array}$ & $\begin{array}{c}-0.498^{*} \\
(0.288)\end{array}$ & $\begin{array}{l}1.311^{* * *} \\
(0.461)\end{array}$ \\
\hline Openness rate & & $\begin{array}{c}0.192 \\
(0.169)\end{array}$ & $\begin{array}{c}0.945 \\
(1.151)\end{array}$ & $\begin{array}{l}-0.459 \\
(0.585)\end{array}$ \\
\hline Trade & & $\begin{array}{l}0.007 \\
(0.027)\end{array}$ & $\begin{array}{c}0.054 \\
(0.101)\end{array}$ & $\begin{array}{l}-0.011 \\
(0.045)\end{array}$ \\
\hline Inflation & & $\begin{array}{l}6.217 * * * \\
(2.394)\end{array}$ & $\begin{array}{c}-1.190 * * * \\
(0.415)\end{array}$ & $\begin{array}{l}-6.069 * * \\
(2.378)\end{array}$ \\
\hline Constant & & & $\begin{array}{c}-35.909 * * \\
(15.562)\end{array}$ & \\
\hline
\end{tabular}

\footnotetext{
Notes: Dependent variable: annual GDP per capita growth. Panel estimations using random effects. Robust standard errors are in parentheses below coefficients. We test for endogeneity by performing the Durbin-WuHausman specification test using the available 5-year lagged variables as instruments. Hausman test results ( $p$-values are 0.57 and 0.80 for East Asia and Latin America, respectively) do not reject the null hypothesis, suggesting that variables are exogenous and the Ordinary Least Square is preferred to instrumental variables estimation. Oaxaca-Blinder decomposition performed with the Oaxaca Stata command developed by Jann [75] ${ }^{* * *} p<0.01,{ }^{* *} p<0.05, * p<0.1$.
}

With respect to East Asia, its growth variability is mainly explained by the accumulation of physical capital, as pointed out by Krugman [76] and Young [77]. Although high investment rates are part of the East Asian success story, our results show that they cannot 
fully explain the high rates of economic growth. According to the theoretical and empirical literature, we find that institutional factors have also played an important role. In line with Kim [78], we find that the rule of law has played a particularly relevant role in the region's sustained growth. The contribution of education to growth is moderate, confirming the results of Lee and Hong [79]. Finally, contrary to the conclusions of other works [80,81], trade has a marginal importance in explaining growth.

In the case of Latin America, growth variability can be mainly explained by human resources and the demographic component of physical capital. Our results are in line with those of Astorga et al. [82], and Vedia-Jerez and Chasco [83]. This increase in the skilled workforce could be behind a substantial percentage of economic growth. Among the human capital components, health is emerging as a factor of extraordinary importance (in line with Weil [56]), even more important than formal education. This effect is found in both regions.

As highlighted by previous studies, we find that, among the institutional factors, government consumption and the inflation rate are important contributors to explain the Latin American growth rate variability [84]. The variable rule of law has a limited effect on the growth of Latin America. Its importance is greater in East Asia, where the economies have been able to benefit from stronger institutions, that have allowed them to promote innovation [85].

Finally, as a key novelty in our analysis, we find that the higher East Asian growth relative to Latin American countries is not due uniquely to higher levels of endowments; that is, East Asian economies are also allocating them more efficiently. In particular, we find that the better use of endowments is especially relevant in the case of investment, government consumption and human resources. As Cavallo and Powell [86] note, the low level and quality of investment is a major factor hindering long-run growth in Latin America. In this regard, some authors have pointed out that East Asia not only has been more successful than Latin America generating policies that supported high levels of investment, but has also provided the necessary institutional support to make this more productive [42]. This better management of investment and government consumption by East Asian institutions could explain, for instance, the faster expansion of public infrastructures and the better provision of education and health services in the region [87].

The differences in taking advantage of the growth factors are also clear in the case of human capital. Its better use by East Asian countries seems to be key to understanding the higher impact of human resources on its economic performance. This result could explain why some studies do not find a significant correlation between the quantity of education and growth rates [41,88]; others, however, do it when they consider the qualitative dimension of human capital, which is related with the efficiency in its use [89].

These results show that, in order to achieve sustainable growth (goal 8), it must be taken into account that the role that human capital, physical capital and institutions can play (goals 3, 4, 9 and 16) will not only depend on the endowments that a country has, but also on the efficiency with which they use and combine them (these and other factors) for the production and distribution of goods and services.

\section{Conclusions and Policy Recommendations}

The 2030 Agenda for Sustainable Development recognizes explicitly the importance of promoting economic growth (goal 8) to achieve sustainable development. In this paper, we exploit the advantages of variance decompositions methods to understand which factors drive the differences in economic growth rates across countries. Thus, the decomposition methods provide a useful tool for policy makers to design effective policies to implement SDGs and promote sustainable development. We illustrate these advantages by analyzing the causes of the contrasting economic growth performance between Latin America and East Asia over the period 1980-2014.

The SOSD reveals, in the case of East Asia, that physical capital and institutional factors are the factors that contribute the most to explaining the economic growth variability. 
In particular, investment rates and the rule of law. For Latin America, human resources, especially health, and physical capital have been the most contributing factors to growth. According to OBD, the economic gap can be mainly explained by differences in the magnitude of endowments in institutional factors and physical capital. In particular, inflation and investment rates are the factors that most help to explain the economic growth divergence. Furthermore, results show that the higher growth of East Asia compared to Latin America is not uniquely explained by the factor endowments but also by the efficiency in their use. The better use of resources by East Asian countries is observed both in physical capital and institutional factors, and is particularly important in the case of human capital.

The empirical identification of the causes that are behind the higher economic growth of East Asia compared with Latin America shows that, since institutional differences are important for understanding economic growth divergence, the institutional infrastructure in Latin America must be a key target. The region should pursue an agenda that prioritizes macroeconomic stability, institutional quality, transparency and governance to make meaningful progress toward the Sustainable Development Goals. In particular, the East Asian experience reveals that reinforcing stabilization is crucial to promote sustained economic growth rates.

Physical capital is the second factor that contributes the most to explaining the higher performance of East Asia compared to Latin America. Establishing appropriate policies to encourage the accumulation and effective use of physical capital appears as a pending task in Latin America, a region with important deficiencies in public infrastructures as transport, telecommunications, energy, water and sanitation. Due to its economic, social and environmental impacts, infrastructure and its uses have a cross-cutting effect on the Sustainable Development Agenda [90]. The role of infrastructure availability in sustainable development is highlighted in goal 9, referring to the development of high-quality, reliable, sustainable and resilient infrastructure. Moreover, goals 6, 7 and 11 explicitly highlight the need to "ensure access to water and sanitation for all", to "ensure access to affordable, reliable, sustainable and modern energy for all" and to "make cities inclusive, safe, resilient and sustainable" [90]. When implementing the SDGs, the need to improve efficiency in the use of resources must always be kept in mind.

Finally, during the Millennium Development Goals era, Latin American countries have made great efforts to improve the quality, efficiency and equity of their public educational systems (goal 4). However, the results highlight that health is even more important than formal education, but the health component of the human capital has been given less attention in the design of public policies that promote growth. Ensuring healthy lives and promoting well-being for all at all ages is essential to sustainable development (goal 3). While the region has made impressive gains against several leading causes of death and disease, various challenges linked to good-quality universal health coverage remain [91].

Despite the technical advantages of the SOSD and OBD methodologies in the study of sustainable economic growth, they also have a number of limitations. It must be borne in mind that these decomposition methods will suffer from some estimation problems as, for example, the presence of omitted variable biases. This does not affect the estimation of the variance, but the components calculated in the decompositions should not be interpreted as accurate causal estimates of the individual impact of a specific factor or group of factors on the dependent variable. They give a measure of their relative importance $[92,93]$. The more efficient the estimator used, the more efficient the resulting decomposition. In this context, a promising line for future research would consist in incorporating other models and estimation techniques that do not presuppose linear relations.

Author Contributions: G.G. and B.B. conceived and designed the research; B.B. drafted the manuscript; B.B. and G.G. performed the econometric analysis; J.S. revised the manuscript; B.B., G.G. and J.S. discussed the results and carried out all the modifications required, thus answering the referee's suggestions. All authors have read and agreed to the published version of the manuscript. 
Funding: This research was funded by the Department of Science, University and Knowledge Society of the Government of Aragón (Foreign Sector and Monetary Integration Research Group).

Institutional Review Board Statement: Not applicable.

Informed Consent Statement: Not applicable.

Data Availability Statement: Publicly available datasets were analyzed in this study. These data can be found here: https:/ / www.gu.se/en/quality-government/qog-data/data-downloads/standarddataset (accessed on 22 February 2019).

Conflicts of Interest: The authors declare no conflict of interest.

\section{Appendix A. Explanation of the Decomposition Methods}

Appendix A.1. Shapley-Owen-Shorrocks Decomposition (SOSD)

SOSD has been applied in the fields of poverty and inequality [15]. The technique combines the Shapley [94] and Owen [95] values, used in cooperative game theory, with the decomposition techniques recently developed by Shorrocks [15]. It allows for the quantification of the relative contribution of each variable, or groups of variables, to a statistical indicator of goodness-of-fit by averaging over all possible combinations on the covariates $[15,74]$. So, it overcomes the path dependency problem. SOSD does not require any assumption or extra effort to allocate residual values. In this sense, the methodology has important advantages, as it satisfies the axioms of (1) efficiency: the goodness of fit of the model is decomposed among the explanatory variables; (2) monotonicity: the increase in R-square-overall must not decrease the value of each component; and (3) equal treatment: perfect substitutes in terms of the goodness of fit receive the same value [74]. Therefore, the factors are treated symmetrically and do not require any further theoretical assumptions.

Following Huettner and Sunder [74], from Equation (A1), we define $\theta$ as a permutation of the variables considering that variable $x_{j}$, has the position $\theta(j)$ in $\theta$. The set of variables that appears before $x_{j}$ in $\theta$ is denoted by $P\left(\theta, x_{j}\right)\left\{x_{p} \in K \mid \theta(p)<\theta(j)\right\}$. In the permutation $\theta$, variable $x_{j}$ changes the R-square by

$$
\operatorname{MC}\left(x_{j}, \theta\right) f\left(P\left(\theta, x_{j}\right) \cup\left\{x_{j}\right\}\right)-\left(P\left(\theta, x_{j}\right)\right)
$$

These are the variable $x_{j}$ 's marginal contributions to $\theta$ over all possible orderings. (The procedure can be applied to the decomposition of any statistic of the model, but it is normally applied to the $R$-square.)

We may now calculate the Owen value of variable $x_{j}$ as

$$
O w_{x j}(f, G)=\frac{1}{|\Theta(K, G)|} \cdot \sum_{\theta \in \Theta(K, G)} M C\left(x_{j} \theta\right)
$$

where $\Theta(K, G)$ is the set of rank orders that respects the partitioning scheme $G$ for all possible permutations, calculated as:

$$
|\Theta(K, G)|=\gamma ! \cdot \prod_{s=1}^{\gamma}\left|G_{s}\right| !
$$

\section{Appendix A.2. Oaxaca-Blinder Decomposition (OBD)}

The OBD was developed in the seminal papers of Oaxaca [17] and Blinder [16]. It studies group differences in an outcome variable by dividing its differential in two parts: the explained one, which accounts for differences in observed characteristics of the population, and the unexplained one, with origin in the differences in the coefficients. The approach was employed initially in labor economics to understand the unexplained part of wage differentials between groups (i.e., gender or race inequalities). 
Decomposition is performed in two stages. In the first one, Equation (A4) is estimated for East Asia and Latin America. Once this is done, the difference between the economic growth rate between the two regions is calculated as follows:

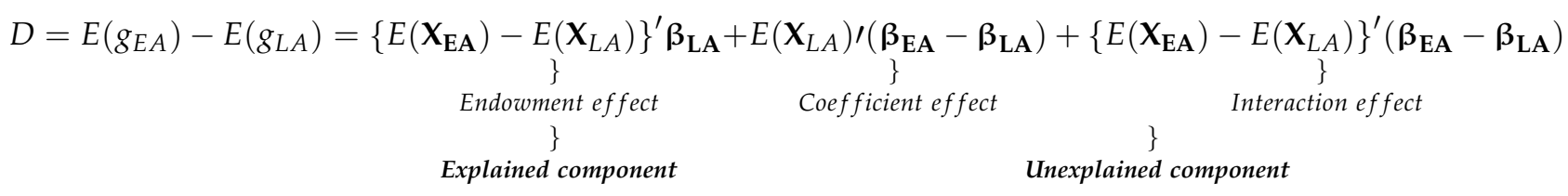

where $E\left(g_{E A}\right)-E\left(g_{L A}\right)$ is the observed difference in the average levels of the economic growth rates between East Asia and Latin America, $X$ the vector of endowments, which groups together the variables that explain the economic growth rate, and $\beta$ the vector of coefficients, including the intercept.

According to Equation (A4), the difference in economic growth rates can be decomposed into two components: the first component represents the effect on the average economic growth rate differential arising from differences in observed characteristics (explained component), whereas the second represents the return of these characteristics (unexplained component). This unobserved component can be decomposed into two effects:

(1) The coefficients effect, which accounts for the differences in the coefficients, including the intercept. It is calculated as the difference in economic growth rates that Latin America would have if they had obtained the same coefficients as East Asia.

(2) The other effect is an interaction effect which accounts for the fact that the differences, both in endowments and coefficients, occur simultaneously in Latin America and East Asia [96].

Appendix B. List of Variables and Countries Included in the Analysis and Summary Statistics 
Table A1. List of variables.

\section{Definition}

GDP per capita growth Initial income

Investment ratio

Fertility rate

Average schooling years

Life expectancy

Government

consumption

Democracy index

Rule of law

Openness rate

Trade

Inflation
Annual percentage growth rate of GDP per capita based on constant local currency.

Real GDP at constant 2011 national prices (in mil. 2011 US\$).

Share of total investment in current local currency and GDP in current local currency. Investment or gross capital

formation is measured by the total value of the gross fixed capital formation and changes in inventories and acquisitions less disposals of valuables for a unit or sector.

Number of children that would be born from a woman if she were to live to the end of her childbearing years and bear children in accordance with age-specific fertility.

Average Schooling Years. Female and Male (15+).

Life Expectancy. Both sexes. Age 0-1 years.

Share of government consumption at current PPPs.

Dichotomous democracy measure. A country is measured as democratic if it satisfies the conditions for both contestation and participation. Specifically, democracies feature political leaders chosen through free and fair elections and satisfy a threshold value of suffrage.

The Rule of Law index includes several indicators which measure the extent to which agents have confidence in and abide by the rules of society. These include perceptions of the incidence of crime, the effectiveness and predictability of the judiciary and the enforceability of contracts. Together, these indicators measure the success of a society in developing an environment in which fair and predictable rules form the basis for economic and social interactions and the extent to which property rights are protected.

The Rule of law variable is available only from 1996. In order to use the entire sample available, we follow the method used by Fernandez-Arias and Montiel (2001) and Blyde and Fernandez-Arias (2004) to construct missing values of the rule of law variable for the subperiods that are not available. This method consists in using a predictive model base on the explanatory variables of the growth model. Consider the following equation: $\mathrm{R}$ it $=\alpha+\beta Z+\mathrm{e}$, where $\mathrm{R}$ it is the

rule of law, and $\mathrm{Z}$ is a set of the explanatory variables included in the growth model (institutional variables and macroeconomic stability). This equation is estimated using data for the subperiods 1985-1989, 1990-1994 and

1995-1999. Then, with the estimated parameters of the model and data values of for the subperiods 1995-1999,

2000-2004 and 1980-1984, we estimate the missing values of the rule of law for periods 1980-1984 and 1985-1989. Ratio of merchandising exports plus imports to GDP at current PPPs.

Growth in terms of trade. Following Barro and Sala-I-Marti (2004), we construct this variable measured by the ratio of export prices to import prices.

Inflation (\% change). Annual percentages of average consumer prices are year-on-year changes.
Source

QOG Standard Dataset

Penn World Table, version 9.0

QOG Standard Dataset

QOG Standard Dataset

QOG Standard Dataset

QOG Standard Dataset

Penn World Table, version 9.0

QOG Standard Datase

QOG Standard Dataset

Penn World Table, version 9.0

Penn World Table, version 9.0 
Table A2. Summary of the mean variables by region.

\begin{tabular}{|c|c|c|c|c|c|c|c|c|}
\hline & \multicolumn{2}{|c|}{ 1980-1990 } & \multicolumn{2}{|c|}{ 1990-2000 } & \multicolumn{2}{|c|}{ 2000-2014 } & \multicolumn{2}{|c|}{ 1980-2014 } \\
\hline & East Asia & $\begin{array}{c}\text { Latin } \\
\text { America }\end{array}$ & East Asia & $\begin{array}{c}\text { Latin } \\
\text { America }\end{array}$ & East Asia & $\begin{array}{c}\text { Latin } \\
\text { America }\end{array}$ & East Asia & $\begin{array}{c}\text { Latin } \\
\text { America }\end{array}$ \\
\hline Per capita GDP growth & 4.58 & -0.72 & 4.00 & 1.95 & 3.90 & 2.33 & 4.12 & 1.37 \\
\hline Initial income in each period & 13.21 & 11.13 & 13.15 & 11.15 & 13.13 & 11.06 & 13.21 & 11.13 \\
\hline Investment ratio & 31.73 & 19.17 & 32.40 & 20.70 & 26.49 & 20.84 & 29.67 & 20.34 \\
\hline Log fertility rate & 0.99 & 1.39 & 0.78 & 1.17 & 0.57 & 0.93 & 0.75 & 1.13 \\
\hline Average schooling years & 6.12 & 5.18 & 7.40 & 6.26 & 9.13 & 7.54 & 7.78 & 6.50 \\
\hline Reciprocal of life expectancy & 0.01 & 0.01 & 0.01 & 0.01 & 0.01 & 0.01 & 0.01 & 0.01 \\
\hline Government consumption ratio & 0.17 & 0.17 & 0.16 & 0.16 & 0.16 & 0.13 & 0.16 & 0.15 \\
\hline Democracy Index & 0.26 & 0.62 & 0.49 & 0.80 & 0.60 & 0.90 & 0.47 & 0.79 \\
\hline Rule of law & -0.10 & -0.14 & 0.19 & -0.24 & 0.41 & -0.51 & 0.21 & -0.33 \\
\hline Openness ratio & 0.77 & 0.35 & 0.68 & 0.36 & 0.59 & 0.35 & 0.67 & 0.35 \\
\hline Trade & 6.79 & 4.81 & 2.07 & 1.57 & 0.36 & 1.32 & 2.68 & 2.39 \\
\hline Inflation rate & 6.45 & 73.39 & 5.80 & 34.55 & 2.85 & 7.58 & 4.66 & 34.27 \\
\hline
\end{tabular}

Table A3. List of countries included in the analysis.

\begin{tabular}{cc}
\hline Latin America & East Asia \\
\hline Argentina & China \\
Bolivia & Indonesia \\
Brazil & Japan \\
Chile & Korea, South \\
Colombia & Malaysia \\
Costa Rica & Philippines \\
Dominican Republic & Singapore \\
Ecuador & Taiwan \\
El Salvador & Thailand \\
Guatemala & \\
Haiti & \\
Honduras & \\
Jamaica & \\
Mexico & \\
Nicaragua & \\
Panama & \\
Paraguay & \\
Peru & \\
Trinidad and Tobago & \\
Uruguay & \\
Venezuela & \\
\hline
\end{tabular}

Note: Countries with population less than 1,000,000 habitants have been excluded in the analysis.

Table A4. Correlation matrix. East Asia (1980-2014).

\begin{tabular}{|c|c|c|c|c|c|c|c|c|c|c|c|c|}
\hline Variables & 1 & 2 & 3 & 4 & 5 & 6 & 7 & 8 & 9 & 10 & 11 & 12 \\
\hline (1) Per capita GDP growth & 1 & & & & & & & & & & & \\
\hline (2) Investment ratio & 0.678 & 1 & & & & & & & & & & \\
\hline (3) Average schooling years & -0.14 & -0.289 & 1 & & & & & & & & & \\
\hline $\begin{array}{c}\text { (4) Government } \\
\text { consumption ratio }\end{array}$ & 0.025 & 0.001 & -0.372 & 1 & & & & & & & & \\
\hline (5) Democracy Index & -0.312 & -0.458 & 0.328 & -0.168 & 1 & & & & & & & \\
\hline (6) Inflation rate & -0.148 & 0.056 & -0.491 & 0.088 & -0.13 & 1 & & & & & & \\
\hline (7) Log fertility rate & -0.229 & -0.096 & -0.592 & 0.185 & -0.143 & 0.605 & 1 & & & & & \\
\hline $\begin{array}{l}\text { (8) Reciprocal of life } \\
\text { expectancy }\end{array}$ & 0.091 & 0.16 & -0.773 & 0.197 & -0.231 & 0.75 & 0.803 & 1 & & & & \\
\hline (9) Openness ratio & 0.044 & 0.161 & -0.098 & -0.313 & -0.389 & -0.244 & -0.219 & -0.228 & 1 & & & \\
\hline (10) Trade & 0.057 & 0.177 & -0.253 & -0.064 & -0.199 & 0.221 & 0.253 & 0.372 & -0.022 & 1 & & \\
\hline (11) Rule of law & -0.355 & -0.255 & 0.599 & -0.06 & 0.142 & -0.518 & -0.56 & -0.721 & 0.326 & -0.069 & 1 & \\
\hline $\begin{array}{l}\text { (12) Initial income in each } \\
\text { period }\end{array}$ & 0.175 & 0.155 & 0.178 & 0.264 & 0.238 & -0.03 & -0.22 & -0.138 & -0.525 & -0.051 & -0.122 & 1 \\
\hline
\end{tabular}


Table A5. Correlation matrix. Latin America (1980-2014).

\begin{tabular}{|c|c|c|c|c|c|c|c|}
\hline Variables & 1 & 2 & 3 & 4 & 5 & 6 & 7 \\
\hline (1) Per capita GDP growth & 1 & & & & & & \\
\hline (2) Investment ratio & 0.257 & 1 & & & & & \\
\hline (3) Average schooling years & 0.407 & 0.132 & 1 & & & & \\
\hline (4) Government consumption ratio & -0.232 & -0.177 & 0.031 & 1 & & & \\
\hline (5) Democracy Index & 0.218 & -0.006 & 0.202 & 0.033 & 1 & & \\
\hline (6) Inflation rate & -0.253 & -0.068 & -0.223 & -0.003 & -0.084 & 1 & \\
\hline (7) Log fertility rate & -0.48 & -0.143 & -0.708 & 0.077 & -0.292 & 0.149 & 1 \\
\hline (8) Reciprocal of life expectancy & -0.444 & -0.322 & -0.549 & 0.154 & -0.13 & 0.251 & 0.703 \\
\hline (9) Openness ratio & -0.035 & -0.153 & 0.046 & 0.199 & 0.151 & -0.244 & -0.008 \\
\hline (10) Trade & -0.095 & 0.031 & 0.028 & 0.168 & 0.091 & 0.118 & 0.139 \\
\hline (11) Rule of law & 0.035 & -0.074 & 0.164 & 0.259 & 0.158 & -0.029 & -0.136 \\
\hline (12) Initial income in each period & -0.044 & 0.032 & -0.06 & -0.029 & -0.14 & 0.35 & -0.135 \\
\hline
\end{tabular}

\section{References}

1. World Commission on Environment and Development. Our Common Future; Oxford University Press: Oxford, UK, 1987.

2. Kurniawan, R.; Managi, S. Economic Growth and Sustainable Development in Indonesia: An Assessment. Bull. Indones. Econ. Stud. 2018, 54, 339-361. [CrossRef]

3. Keeble, B.R. The Brundtland Commission: Environment and Development to the Year 2000. Med. War 1987, 3, 207-210. [CrossRef]

4. Harlow, J.; Golub, A.; Allenby, B. A Review of Utopian Themes in Sustainable Development Discourse. Sustain. Dev. 2013, 21, 270-280. [CrossRef]

5. Transforming Our World: The 2030 Agenda for Sustainable Development I Department of Economic and Social Affairs. Available online: https:/ /sdgs.un.org/publications/transforming-our-world-2030-agenda-sustainable-development-17981 (accessed on 1 June 2021).

6. Arrow, K.J.; Dasgupta, P.; Goulder, L.H.; Mumford, K.J.; Oleson, K. Sustainability and the Measurement of Wealth. Environ. Dev. Econ. 2012, 17, 317-353. [CrossRef]

7. Elliott, J. An Introduction to Sustainable Development; Routledge: London, UK, 2012; ISBN 9781136918278.

8. Barro, R.J. Economic Growth in a Cross Section of Countries. Q. J. Econ. 1991, 106, 407. [CrossRef]

9. Barro, R.; Sala i Martín, X. Crecimiento Económico; Editorial Reverté: Barcelona, Spain, 2009; ISBN 9788429126143.

10. Jones, C.I. The Facts of Economic Growth. Handb. Macroecon. 2016, 2, 3-69.

11. Wasserstein, R.L.; Lazar, N.A. The ASA Statement on p-Values: Context, Process, and Purpose. Am. Stat. 2016, 70, 129-133. [CrossRef]

12. Israeli, O. A Shapley-Based Decomposition of the R-Square of a Linear Regression. J. Econ. Inequal. 2007, 5, 199-212. [CrossRef]

13. Nathans, L.; Oswald, F.; Nimon, K. Interpreting Multiple Linear Regression: A Guidebook of Variable Importance. Pract. Assess. Res. Eval. 2012, 17, 9. [CrossRef]

14. Baye, F.M. Growth, Redistribution and Poverty Changes in Cameroon: A Shapley Decomposition Analysis. J. Afr. Econ. 2006, 15, 543-570. [CrossRef]

15. Shorrocks, A.F. Decomposition Procedures for Distributional Analysis: A Unified Framework Based on the Shapley Value. J. Econ. Inequal. 2013, 11, 99-126. [CrossRef]

16. Blinder, A.S. Wage Discrimination: Reduced Form and Structural Estimates. J. Hum. Resour. 1973, 8, 436. [CrossRef]

17. Oaxaca, R. Male-Female Wage Differentials in Urban Labor Markets. Int. Econ. Rev. 1973, 14, 693. [CrossRef]

18. Liao, P.-A.; Chang, H.-H.; Wang, J.-H.; Sun, L.-C. What Are the Determinants of Rural-Urban Digital Inequality among Schoolchildren in Taiwan? Insights from Blinder-Oaxaca Decomposition. Comput. Educ. 2016, 95, 123-133. [CrossRef]

19. Castro Aristizabal, G.; Giménez, G.; Pérez Ximénez-de-Embún, D. Estimación de Los Factores Condicionantes de La Adquisición de Competencias Académicas En América Latina En Presencia de Endogeneidad. Rev. CEPAL 2018, 2018, 35-59. [CrossRef]

20. Giménez, G.; Castro Aristizábal, G. ¿Por Qué Los Estudiantes de Colegios Públicos y Privados de Costa Rica Obtienen Distintos Resultados Académicos? Perf. Latinoam. 2017, 25, 195-223. [CrossRef]

21. Gimenez, G.; Barrado, B.; Arias, R. El Papel Del Profesorado y El Entorno de Aprendizaje En El Rendimiento de Los Estudiantes Costarricenses: Un Análisis a Partir de PISA. Rev. Complut. Educ. 2019, 30, 1127-1145. [CrossRef]

22. Gimenez, G.; Martín-Oro, Á.; Sanaú, J. The Effect of Districts' Social Development on Student Performance. Stud. Educ. Eval. 2018, 58, 80-96. [CrossRef]

23. Castro Aristizabal, G.; Giménez, G.; Pérez Ximénez-De-Embún, D. Desigualdades Educativas En América Latina, PISA 2012: Causas de Las Diferencias En Desempeño Escolar Entre Los Colegios Públicos y Privados. Rev. Educ. 2017, 2017, 33-59. [CrossRef]

24. Morduch, J.; Sicular, T. Rethinking Inequality Decomposition, with Evidence from Rural China. Econ. J. 2002, 112, 93-106. [CrossRef]

25. Solow, R.M. A Contribution to the Theory of Economic Growth. Q. J. Econ. 1956, 70, 65. [CrossRef]

26. Hulten, C.R. Growth Accounting*. In Handbook of the Economics of Innovation; Elsevier: Amsterdam, The Netherlands, 2010; Volume 2, pp. 987-1031. 
27. Hulten, C. Total Factor Productivity: A Short Biography. In New Developments in Productivity Analysis; University of Chicago Press: Chicago, IL, USA, 2001.

28. Mankiw, N.G.; Romer, D.; Weil, D.N. A Contribution to the Empirics of Economic Growth. Q. J. Econ. 1992, 107, 407-437. [CrossRef]

29. Aghion, P.; Comin, D.; Howitt, P.; Tecu, I. When Does Domestic Savings Matter for Economic Growth? IMF Econ. Rev. 2016, 64, 381-407. [CrossRef]

30. Brock, W.A. What Have We Learned from a Decade of Empirical Research on Growth? Growth Empirics and Reality. World Bank Econ. Rev. 2001, 15, 229-272. [CrossRef]

31. Quah, D. Empirical Cross-Section Dynamics in Economic Growth. Eur. Econ. Rev. 1993, 37, 426-434. [CrossRef]

32. Amini, S.; Battisti, M.; Parmeter, C.F. Decomposing Changes in the Conditional Variance of GDP over Time. Econ. Model. 2017, 61, 376-387. [CrossRef]

33. Durlauf, S.N. Manifesto for a Growth Econometrics. J. Econom. 2001, 100, 65-69. [CrossRef]

34. Casey, G.; Klemp, M. Instrumental Variables in the Long Run. SSRN Electron. J. 2017. [CrossRef]

35. Montgomery, M.R.; Birdsall, N.; Jaspersen, F. Pathways to Growth: Comparing East Asia and Latin America. Stud. Fam. Plan. 1997, 28, 349. [CrossRef]

36. Blyde, J.; Fernández-Arias, E. Why Does Latin America Grow More Slowly? Inter-American Development Bank: Washington, DC, USA, 2004; Available online: https:/ / publications.iadb.org/publications/english/document/Why-does-Latin-America-GrowMore-Slowly.pdf (accessed on 9 June 2021).

37. Haggard, S. Book Review: Nancy Birdsall and Frederick Jasperson (Eds.), Pathways to Growth: Comparing East Asia and Latin America (Washington, DC: Inter-American Development Bank, 1997, 323 Pp., £16.50 Pbk.). Millenn. J. Int. Stud. 1997, 26, 904-906. [CrossRef]

38. Hanushek, E.A.; Woessmann, L. Schooling, Educational Achievement, and the Latin American Growth Puzzle. J. Dev. Econ. 2012, 99, 497-512. [CrossRef]

39. Hanushek, E.A.; Woessmann, L. Knowledge Capital, Growth, and the East Asian Miracle. Science 2016, 351, 344-345. [CrossRef]

40. Comeau, L. The Political Economy of Growth in Latin America and East Asia: Some Empirical Evidence. Contemp. Econ. Policy 2003, 21, 476-489. [CrossRef]

41. De Gregorio, J.; Lee, J.-W. Growth and Adjustment in East Asia and Latin America. Economía 2004, 5, 69-134. [CrossRef]

42. Elson, A. The Economic Development of East Asia and Latin America in Comparative Perspective. In Globalization and Development; Palgrave Macmillan US: New York, NY, USA, 2013; pp. 19-35.

43. Gereffi, G. Contending Paradigms for Cross-Regional Comparison: Development Strategies and Commodity Chains in East Asia and Latin America. In New Approaches to Methods and Analysis; Routledge: London, UK, 2018; pp. 33-58.

44. Myrskylä, M.; Kohler, H.-P.; Billari, F.C. Advances in Development Reverse Fertility Declines. Nature 2009, 460, 741-743. [CrossRef] [PubMed]

45. Lacalle-Calderon, M.; Perez-Trujillo, M.; Neira, I. Fertility and Economic Development: Quantile Regression Evidence on the Inverse J-Shaped Pattern. Eur. J. Popul. 2017, 33, 1-31. [CrossRef]

46. Doepke, M. Accounting for Fertility Decline During the Transition to Growth. SSRN Electron. J. 2001. [CrossRef]

47. Barro, R.J. International Data on Educational Attainment: Updates and Implications. Oxf. Econ. Pap. 2001, 53, 541-563. [CrossRef]

48. Barro, R.J.; Lee, J.W. A New Data Set of Educational Attainment in the World, 1950-2010. J. Dev. Econ. 2013, 104, 184-198. [CrossRef]

49. Hanushek, E. The Failure of Input-Based Schooling Policies. Econ. J. 2003, 113, 64-98. [CrossRef]

50. Giménez, G.; López-Pueyo, C.; Sanaú, J. Human Capital Measurement in OECD Countries and Its Relation to GDP Growth and Innovation. Rev. Econ. Mund. 2015, 39, 77-108.

51. Labordeta, J.F.-R.; Giménez, G. The Effect of Human Capital on Innovation: Analysis from the Quantitative and Qualitative Perspectives of Education. Intang. Cap. 2012, 8, 425-446. [CrossRef]

52. Gimenez, G.; Sanau, J. Investment, Human Capital and Institutions: A Multi-Equational Approach for the Study of Economic Growth. Appl. Econom. Int. Dev. 2009, 9. Available online: https://dialnet.unirioja.es/servlet/articulo? codigo=7446736 (accessed on 10 June 2021).

53. Barcenilla, S.; Gimenez, G.; López-Pueyo, C. Differences in Total Factor Productivity Growth in the European Union: The Role of Human Capital by Income Level. Prague Econ. Pap. 2019, 28, 70-85. [CrossRef]

54. López-Pueyo, C.; Barcenilla, S.; Giménez, G. The Two Faces of Human Capital and Their Effect on Technological Progress. Panoeconomicus 2018, 65, 163-181. [CrossRef]

55. Gimenez, G. The Human Capital Endowment of Latin America and the Caribbean. CEPAL Rev. 2005, 86, 97-116. [CrossRef]

56. Weil, D.N. Health and Economic Growth. In Handbook of the Economics of Innovation; Elsevier: Amsterdam, The Netherlands, 2014; Volume 2, pp. 623-682.

57. Bloom, D.; Canning, D.; Kotschy, R.; Prettner, K.; Schünemann, J. Health and Economic Growth: Reconciling the Micro and Macro Evidence; National Bureau of Economic Research: Cambridge, MA, USA, 2019. [CrossRef]

58. Bassanini, A.; Scarpetta, S. The Driving Forces of Economic Growth. OECD Econ. Stud. 2003, 2001, 9-56. [CrossRef]

59. Connolly, M.; Li, C. Government Spending and Economic Growth in the OECD Countries. J. Econ. Policy Reform 2016, 19, 386-395. [CrossRef] 
60. Della Posta, P. Government Size and Speculative Attacks on, Public Debt. Int. Rev. Econ. Financ. 2021, 72, 79-89. [CrossRef]

61. Kaufmann, D.; Kraay, A.; Mastruzzi, M. The Worldwide Governance Indicators: Methodology and Analytical Issues. Hague J. Rule Law 2011, 3, 220-246. [CrossRef]

62. Acemoglu, D.; Johnson, S.; Robinson, J.A. Chapter 6 Institutions as a Fundamental Cause of Long-Run Growth. In Handbook of the Economics of Innovation; Elsevier: Amsterdam, The Netherlands, 2005; Volume 1, pp. 385-472.

63. Acemoglu, D.; Naidu, S.; Restrepo, P.; Robinson, J.A. Democracy Does Cause Growth. J. Political Econ. 2019, 127, 47-100. [CrossRef]

64. Gimenez, G. Introducción al Crecimiento Económico y Desarrollo; Ediciones Pirámide: Madrid, Spain, 2017 ; ISBN 8436836766.

65. Giménez, G.; Sanaú, J. Interrelationship among Institutional Infrastructure, Technological Innovation and Growth. An Empirical Evidence. Appl. Econ. 2007, 39, 1267-1282. [CrossRef]

66. Doucouliagos, H.; Ulubaşoğlu, M.A. Democracy and Economic Growth: A Meta-Analysis. Am. J. Political Sci. 2008, 52, 61-83. [CrossRef]

67. Freund, C.; Bolaky, B. Trade, Regulations, and Income. J. Dev. Econ. 2008, 87, 309-321. [CrossRef]

68. Falvey, R.; Foster, N.; Greenaway, D. Trade Liberalization, Economic Crises, and Growth. World Dev. 2012, 40, 2177-2193. [CrossRef]

69. Marelli, E.; Signorelli, M. China and India: Openness, Trade and Effects on Economic Growth. Eur. J. Comp. Econ. 2011, 8, 129-154.

70. Tanveer Choudhry, M.; Marelli, E.; Signorelli, M. China and India's Global Integration in the Process of Economic Development. In China-India Relations. Understanding China; Springer: Cham, Switzerland, 2020; pp. 59-80.

71. Fischer, S. The Role of Macroeconomic Factors in Growth. J. Monet. Econ. 1993, 32, 485-512. [CrossRef]

72. Kremer, S.; Bick, A.; Nautz, D. Inflation and Growth: New Evidence from a Dynamic Panel Threshold Analysis. Empir. Econ. 2013, 44, 861-878. [CrossRef]

73. Huettner, F.; Sunder, M. Axiomatic Arguments for Decomposing Goodness of Fit According to Shapley and Owen Values. Electron. J. Stat. 2012, 6, 1239-1250. [CrossRef]

74. Jann, B. The Blinder-Oaxaca Decomposition for Linear Regression Models. Stata J. Promot. Commun. Stat. Stata 2008, 8, 453-479. [CrossRef]

75. Krugman, P. The Myth of Asia's Miracle. Foreign Aff. 1994, 73, 62. [CrossRef]

76. Young, A. The Tyranny of Numbers: Confronting the Statistical Realities of the East Asian Growth Experience. Q. J. Econ. 1995, 110, 641-680. [CrossRef]

77. Kim, E. Trade Liberalization and Productivity Growth in Korean Manufacturing Industries: Price Protection, Market Power, and Scale Efficiency. J. Dev. Econ. 2000, 62, 55-83. [CrossRef]

78. Lee, J.-W.; Hong, K. Economic Growth in Asia: Determinants and Prospects; Asian Development Bank Economics Working Paper Series No. 220; Asian Development Bank: Mandaluyong, Philippines, 2010. [CrossRef]

79. Sazanami, Y. The East Asian Miracle: Economic Growth and Public Policy. A World Bank Policy Research Report. London: Oxford University Press, 1993. xvii, 289 pp. J. Asian Stud. 1995, 54, 184-185. [CrossRef]

80. Lu, S.-S. East Asian Growth Experience Revisited from the Perspective of a Neoclassical Model. Rev. Econ. Dyn. 2012, 15, 359-376. [CrossRef]

81. Astorga, P. A Century of Economic Growth in Latin America. J. Dev. Econ. 2010, 92, 232-243. [CrossRef]

82. Vedia-Jerez, D.H.; Chasco, C. Long-Run Determinants of Economic Growth in South America. J. Appl. Econ. 2016, 19, 169-192. [CrossRef]

83. De Gregorio, J. El Crecimiento Económico de La América Latina. Del Desencanto Del Siglo XX a Los Desafíos Del XXI. Trimest. Econ. 2017, 75, 5. [CrossRef]

84. Nelson, R.R.; Pack, H. The Asian Miracle and Modern Growth Theory. Econ. J. 1999, 109, 416-436. [CrossRef]

85. Cavallo, E.A.; Powell, A. 2018 Latin American and Caribbean Macroeconomic Report: A Mandate to Grow; Inter-American Development Bank: Washington, DC, USA, 2018. [CrossRef]

86. McGuire, J.W.; Lancaster, C. The Politics of Development in Latin America and East Asia; Lancaster, C., van de Walle, N., Eds.; Oxford University Press: Oxford, UK, 2016; Volume 1.

87. Fernandez-Arias, E.; Montiel, P.J. Reform and Growth in Latin America: All Pain, No Gain? IADB Research Department Working Paper No. 351.; Inter-American Development Bank: Washington, DC, USA, 1997. [CrossRef]

88. Hanushek, E.A.; Kimko, D.D. Schooling, Labor-Force Quality, and the Growth of Nations. Am. Econ. Rev. 2000, 90, 1184-1208. [CrossRef]

89. Governance of Infrastructure for Sustainable Development in Latin America and the Caribbean: An Initial Premise I Publication I Economic Commission for Latin America and the Caribbean. Available online: https:/ /www.cepal.org/en/publications/42108governance-infrastructure-sustainable-development-latin-america-and-caribbean (accessed on 1 June 2021).

90. PAHO; WHO. Sustainable Health Agenda for the Americas 2018-2030. 2018. Available online: https://www.paho.org/en/ sustainable-health-agenda-americas-2018-2030 (accessed on 10 June 2021).

91. Ferreira, F.H.G.; Gignoux, J. The Measurement of Educational Inequality: Achievement and Opportunity1. World Bank Econ. Rev. 2014, 28, 210-246. [CrossRef]

92. Shapley, L.S. Stochastic Games. Proc. Natl. Acad. Sci. USA 1953, 39, 1095-1100. [CrossRef] [PubMed] 
93. Owen, G. Values of Games with a Priori Unions. In Mathematical Economics and Game Theory; Springer: Berlin/Heidelberg, Germany, 1977; pp. 76-88.

94. Castro, G.; Gimenez, G.; Sanaú, J. Educational Inequalities in Latin America, PISA 2012: Causes of Differences in School Performance between Public and Private Schools. Rev. Educ. 2017, 376, 32-59. [CrossRef]

95. Maneejuk, P.; Yamaka, W. The Impact of Higher Education on Economic Growth in ASEAN-5 Countries. Sustainability 2021, 13, 520. [CrossRef]

96. Wen, H.; Dai, J. The Change of Sources of Growth and Sustainable Development in China: Based on the Extended EKC Explanation. Sustainability 2021, 13, 2803. [CrossRef] 